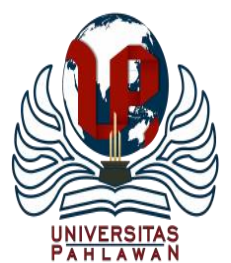

Edukatif : Jurnal Ilmu Pendidikan Volume 3 Nomor 5 Tahun 2021 Halm 2874 - 2885

EDUKATIF: JURNAL ILMU PENDIDIKAN

Research \& Learning in Education

https://edukatif.org/index.php/edukatif/index

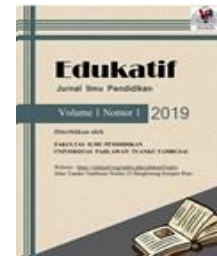

\title{
Penggunaan Google Classroom oleh Siswa dalam Pembelajaran Pendidikan Agama Islam di Masa Pandemic Covid 19
}

\author{
Aris Fajar Kusumah ${ }^{1 凶}$, Oyoh Bariyah ${ }^{2}$, Khalid Ramdhani ${ }^{3}$ \\ Universitas Singaperbangsa Karawang, Indonesia ${ }^{1,2,3}$ \\ E-mail : arisfajarkusumah@gmail.com¹ ${ }^{1}$ oyoh.bariah@ staff.unsika.ac.id ${ }^{2}, \underline{\text { khalid.ramdhani@ fai.unsika.ac.id }}^{3}$
}

\begin{abstract}
Abstrak
Pandemic Covid-19 telah mendorong guru penddidikan Agama Islam beralih menggunakan sistem pembelajaran online atau daring. Googe Classroom (GCR) dimanfaatkan sebagai platform dalam memfasilitasi kebutuhan belajar guru dan siswa. Penelitian mengkaji bagaimana penggunaan Google Classroom oleh siswa dalam pembelajaran Pendidikan Agama Islam. Penelitian ini merupakan penelitian campuran dengan metode explanatory dan melibatkan 75 siswa kelas VIII SMP negeri 2 Telukjambe Timur kabupaten Karawang. Pengumpulan data melalui angket, observasi dan wawancara. Hasil penelitian menunjukkan kemudahan akses GCR $(4,11)$, manfaat yang dirasakan siswa $(3,88)$, komunikasi dan interaksi $(3,83)$, pengiriman intruksi $(3,87)$, dan kepuasan siswa $(3,88)$. Beberapa siswa berbagi pengalaman mereka dalam menggunakan GCR. Beberapa dari mereka mengatakan bahwa GCR menghadirkan pembelajaran yang fleksibel sehingga mereka dapat berpartisipasi dan melanjutkan pekerjaan mereka kelas di luar jam kerja. Bahkan banyak dari mereka yang masih bekerja dan mengunggah tugas mereka sampai tengah malam. Terlepas dari temuan positif ini, penelitian mengungkapkan bahwa beberapa siswa jatuh ke dalam masalah serius kecanduan teknologi media sosial dan mengalami kesulitan mengontrol diri ke arah pembelajaran yang diharapkan.
\end{abstract}

Kata Kunci: Pendidikan Agama Islam, Pembelajaran Daring, Google Classroom.

\section{Abstract}

The Covid-19 pandemic has pushed Islamic education teachers to switch to using online or online learning systems. Google Classroom is used as a platform to facilitate the learning needs of teachers and students. This study examines how students use Google Classroom in learning Islamic Religious Education. This research is a mixed research with explanatory methods and involves 75 students of class VIII SMP Negeri 2 Telukjambe Timur, Karawang district. Collecting data through questionnaires, observations and interviews. The results showed the ease of access to GCR (4.11), the benefits felt by students (3.88), communication and interaction (3.83), delivery of instructions (3.87), and student satisfaction (3.88). Several students shared their experiences in using GCR. Some of them said that GCR provided flexible learning so that they could participate and continue their class work out(side of working hours. In fact, many of them are still working and uploading their assignments until midnight. Despite these positive findings, the study revealed that some students fell into serious problems of addiction to social media technology and had difficulty controlling themselves in the expected learning.

Keywords: Islamic Religious Education, Online Learning, Google Classroom.

Copyright (c) 2021 Aris Fajar Kusumah, Oyoh Bariyah, Khalid Ramdhani

$\square$ Corresponding author

Email : arisfajarkusumah@gmail.com

DOI : https://doi.org/10.31004/edukatif.v3i5.1011 
2875 Penggunaan Google Classroom oleh Siswa dalam Pembelajaran Pendidikan Agama Islam di Masa Pandemic Covid 19 - Aris Fajar Kusumah, Oyoh Bariyah, Khalid Ramdhani

DOI: https://doi.org/10.31004/edukatif.v3i5.1011

\section{PENDAHULUAN}

Sejak Maret 2020, kasus penyebaran virus corona atau yang dikenal dengan Covid-19 telah menjadi pandemi global (Rahayu \& Wirza, 2020). Peningkatan penularan virus corona memaksa kebijakan jarak sosial untuk meminimalkan ruang Covid-19 (Pokhrel \& Chhetri, 2021). Beberapa penelitian menemukan fenomena bahwa pandemi Covid-19 juga berdampak pada berdampak besar terhadap sektor pendidikan (Rahardjo \& Pertiwi, 2020). Di bidang pendidikan, Kementerian Pendidikan \& Kebudayaan Republik Indonesia melalui surat edaran Nomor 4 Tahun 2020 yang dikeluarkan pada 24 Maret 2020, mengintruksikan diimplementasikannya belajar dari rumah (School From Home/SFH) dengan pembelajaran jarak jauh secara daring/online memanfaatkan akses teknologi internet (Dewi, 2020).

Saat ini kemajuan teknologi internet dan digital hampir terjadi di seluruh negara di berbagai belahan dunia (Taufik, 2020). Banyak pula penelitian yang melaporkan beragam manfaat teknologi digital untuk mendukung aktivitas belajar siswa (Salam, 2020). Pesatnya perkembangan teknologi digital mampu menghasilkan inovasi sehingga menciptakan lingkungan belajar yang kaya untuk memungkinkan siswa tidak sebatas mengakses informasi dan komunikasi yang mereka butuhkan, tetapi juga menyediakan tempat sehingga mereka dapat melatih pembelajaran inkuiri, berpikir kritis, kreativitas, dan kolaborasi (Tsai et al., 2021).

Kebijakan SFH mewajibkan proses belajar mengajar yang awalnya secara tatap muka di mana guru dan siswa belajar dan bertemu di kelas dalam waktu yang sama, kini harus dilaksanakan dengan konsekuensi guru dan siswa tidak bertemu langsung di sekolah (Putra et al., 2020). Pembelajaran di kelas harus digantikan dengan ruang-ruang digital atua dunia maya (Mahyoob, 2020). Kendati demikian, dengan pemanfaatan teknologi terkini yang mendukung pembelajaran, guru tetap dapat menyampaikan materi ajar, dan siswa tetap dapat menerima pelajaran tanpa harus keluar rumah (Handarini, 2020).

Pembelajaran jarak jauh secara daring yang diintruksikan, menginisiasi guru Pendidikan Agama Islam beradaptasi dan meng-upgrade skill guna mencapai tujuan pembelajaran secara online. Guru selaku edukator, fasilisator dan motivator yang mengarahkan siswa dalam mencapai tujuan pembelajaran dituntut mampu memilih dan mendesain pembelajaran secara daring dengan media yang tepat, efektif dan efisien (Asmawati \& Bintang Kejora, 2020). Dan harus disadari bahwa kondisi pandemic Covid 19 dengan intruksi pembelajaran online dari rumah merupakan peluang bagi guru dan siswa untuk melakukan transformasi teknologi dan memulai membuka kelas-kelas yang memanfaatkan teknologi (Indrawati, 2020).

Berbagai acara seminar dan diskusi pendidikan digelar dan memperbincangkan bagaimana teknologi membantu pembelajaran, kekurangan, dan dampak positif teknologi bagi penggunanya (El Fauziah et al., 2019). Disimpulkan pula bahwa siswa generasi hari ini sangat akrab dengan penggunaan teknologi internet untuk komunikasi dan game yang seharusnya pula memudahkan mereka memperoleh akses dan pengalaman belajar (Gan et al., 2015). Kendati faktanya masih ditemukan siswa yang cenderung kurang memperhatikan penjelasan gurunya, terkendala akses jaringan internet, dan kesulitan dalam fasilitas lainnya (Wahyuningsih, 2021). Adapula siswa yang justru terganggu oleh apa yang disajikan guru dalam pembelajaran. Fenomena ini sebenarnya menunjukkan ketidakmampuan siswa untuk menggunakan TIK untuk niat belajar (Widodo \& Nursaptini, 2020). Dengan demikian kemampuan siswa untuk menggunakan dan menerima teknologi tersebut untuk kegiatan belajar memerlukan desain instruksional yang disediakan oleh guru mereka. Guru harus mampu membuat refleksi diperlukannya metode dan media yang mendukung pembelajaran yang dapat bersifat asyncronus dan memfasilitasi tugas dalam satu platform atau aplikasi pembelajaran (Mustakim, 2020).

Studi pendahuluan pada pembelajaran PAI kelas VIII di SMP Negeri 2 Telukjambe Karawang Timur, salah satu platform yang digunakan sebagai upaya optimalisasi pembelajaran PAI adalah dengan memanfaatkan Google classroom (GCR). Pemanfaatan google classsroom dalam pembelajaran PAI diawali dengan pembuatan akun GCR menggunakan email oleh guru. Setelah akun GCR aktif, dilanjutkan dengan 
membuat kelas kemudian meminta siswa bergabung ke dalam kelas (GCR) melalui link yang dibagikan. Guru mempublikasikan apapun mengenai pembelajaran termasuk materi, diskusi, tugas dan evaluasi.

Saat ini GCR telah menjadi salah satu platform pengajaran yang populer digunakan dalam pembelajaran dan telah berhasil menampung lebih dari 30 juta tugas yang diunggah oleh guru dan siswa (Mu'minah \& Gaffar, 2020). Pemanfaatan GCR bisa dilakukan secara multiplatform, yaitu melalui komputer dan perangkat android atau handphone (Sabran \& Sabara, 2019). Pemilihan GCR dalam pembelajaran PAI di SMP diekspektasikan untuk memudahkan guru dalam mengelola pembelajaran dan menyampaikan informasi secara akurat kepada siswa (Hapsari \& Pamungkas, 2019).

Ali and Maksum (2020) dalam penelitiannya menjelaskan pembelajaran daring berbantuan Googleclassroom, membuat siswa menjadi nyaman untuk aktif membangun pengetahuan mereka. Pendidik juga dapat memanfaatkan berbagai fitur yang terdapat di aplikasi Googleclassroom kelas seperti tugas, penilaian, komunikasi, biaya waktu, arsip kursus, seluler aplikasi, dan privasi. GCR juga membantu guru menumbuhkan kemandirian belajar, kedisiplinan siswa, dan kompetensi lain yang diperlukan siswa (Efriana, 2021).

Pada penelitian sebelumnya Salam (2020) meneliti mengenai penggunaan Google Clasroom pada pembelajaran bahasa Inggris di perguruan tinggi yang menggambarkan efektififtas Google Classroom menghadirkan pembelajaran sehingga siswa dapat berpartisipasi dan melanjutkan tugas hingga larut malam. Penelitian lainnya dilakukan oleh Wicaksono \& Rachmadyanti (2016) meneliti tentang google classroom di sekolah dasar. Hasil penelitian menunjukkan bahwa GCR berfungsi sebagai media alternatif dalam pembelajaran yang dapat memberikan akses dalam melakukan pembelajaran secara daring bagi siswa. Tak hanya itu, guru pundapat memberikan pembelajaran meskipun tidak di dalam kelas, sehingga memfasilitasi pengawasan guru terhadap siswanya ketika di luar sekolah.

Beberapa penelitiaan mengenai pembelajaran di masa pandemic telah banyak dilakukan dengan pemanfaatan media google classroom sebagai topik penelitian dengan subjek penelitian mahasiswa dan siswa SD dengan ketersediaan akses dan fasilitas yang lebih memadai. Meskipun terdapat kesamaan topik penelitian dengan penelitian sebelumnya, namun sasaran, subjek dan objek akademik yang diteliti dalam penelitian ini berbeda. Pada penelitian ini, penulis mengkaji bagaimana penggunaan Google Classroom dengan objek akademik adalah mata pelajaran Pendidikan Agama Islam. Sasaran penelitian adalah siswa SMP dengan ketersedian fasilitas, akses jaringan dan kemampuan IT yang masih terbatas serta belum akrab dengan teknologi internet.

\section{METODE PENELITIAN}

Penelitian ini merupakan penelitian campuran dengan metode explanatory (Saunders et al., 2016). Studi ini mengumpulkan, menganalisis, dan menggabungkan data kuantitatif dan kualitatif (Sugiyono, 2016) untuk menganalisis dan mengevaluasi respon siswa mengenai pembelajaran PAI memanfaatkan GCR. Penelitian melibatkan 75 siswa kelas VIII SMP negeri 2 Telukjambe Timur kabupaten Karawang.

Data dikumpulkan melalui survei, wawancara, dan observasi. Survei terlebih dahulu diselesaikan dan kemudian wawancara dan observasi digunakan sebagai tindak lanjut untuk mencerahkan hasil kuantitatif. Data kuantitatif memberikan informasi yang luas tentang respon siswa mengenai pembelajaran PAI berbantuan GCR. Di sisi lain, data kualitatif memberikan deskripsi yang kaya tentang pelaksanaan pembelajaran dengan kuantitas sampel yang lebih kecil. Oleh karena itu, penelitian ini menghasilkan temuan yang saling melengkapi antara data kuantittaif dengan kualitatif (Suharsaputra, 2012).

Kusioner berskala likert (1-5) digunakan untuk pengumpulan data (Nurabadi et al., 2021) mencakup akses siswa dalam pembelajaran, kebermanfaatan yang dirasakan siswa, komunikasi dan interaksi. Setelah data kuantitatif dikumpulkan, selanjutnya adalah menganalisa dan menentukan skor rata-rata setiap item 
2877 Penggunaan Google Classroom oleh Siswa dalam Pembelajaran Pendidikan Agama Islam di Masa Pandemic Covid 19 - Aris Fajar Kusumah, Oyoh Bariyah, Khalid Ramdhani

DOI: https://doi.org/10.31004/edukatif.v3i5.1011

(Creswell, 2014). Data dalam bentuk skor atau angka diidentifikasi menggunakan interval Bringula (Bringula, 2012; Salam, 2020) dengan skala 5 poin penskoran.

Tabel 1. Interprestasi Verbal

\begin{tabular}{cccc}
\hline No & Rentang Nilai/Skor & $\%$ & Kriteria \\
\hline 1. & $1,00-1,80$ & $20 \%-36 \%$ & Sangat Rendah \\
\hline 2. & $1,81-2,60$ & $37 \%-52 \%$ & Rendah \\
\hline 3. & $2,61-3,40$ & $53 \%-68 \%$ & Cukup \\
\hline 4. & $3,41-4,20$ & $69 \%-84 \%$ & Baik \\
\hline 5. & $4,21-5,00$ & $83 \%-100 \%$ & Sangat Baik \\
\hline
\end{tabular}

Data kualitatif dianalisis dengan teknik deskriptif dan triangulasi untuk memperoleh data yang akurat dan akuntabel dengan mencocokkan data yang diperoleh melalui survei, wawancara, dokumentasi dan observasi yang dipantau dan dibimbing oleh tim peneliti (Moleong, 2018).

\section{HASIL DAN PEMBAHASAN PENELITIAN}

\section{Penggunaan Google Kelas oleh Siswa}

Temuan penelitian disajikan dalam dua bagian, pertama melaporkan penggunaan aplikasi Google Classroom oleh siswa dalam pembelajaran PAI. Sedangkan bagian kedua memaparkan pengalaman siswa dalam menggunakan Google Classroom. Kajian temuan pertama adalah melaporkan akses kemudahan siswa ke Google Classroom.

Tabel 2. Kemudahan Akses

\begin{tabular}{clrrc}
\hline No & \multicolumn{1}{c}{ Aspek } & Rata-Rata & \% & Interprestasi \\
\hline 1 & Mudah untuk masuk (sign in) & 4,44 & 88,80 & Sangat baik \\
\hline 2 & kemudahan mengakses materi ajar & 3,56 & 71,20 & Baik \\
\hline 3 & Kemudahan untuk menerima tugas & 4,33 & 86,60 & Sangat baik \\
\hline 4 & Mudah untuk mengumpulkan tugas & 4,41 & 88,20 & Sangat baik \\
\hline 5 & kemudahan mengoperasikan GCR & 3,78 & 75,60 & baik \\
\hline 6 & Mudah untuk memahami sistem & 4,13 & 82,60 & baik \\
\hline & Rata-Rata & 4,11 & 82,17 & Baik \\
\hline
\end{tabular}

Data menunjukkan bahwa hampir semua siswa menjawab sangat baik pada 3 aspek yaitu mudah untuk masuk (sign in), kemudahan untuk menerima tugas, dan mudah untuk mengumpulkan tugas. Pada tiga aspek lainnya, sebagian besar siswa merespon baik. Skor tertinggi pada aspek kemudahan untuk masuk/sign in $(4,44)$, dan skor terendah pada aspek kemudahan mengoperasikan GCR $(3,78)$. Hal ini menunjukkan bahwa beberapa siswa mungkin masih merasa asing dan belum terbiasa dengan Google Classroom. Namun hal ini menjadi pengalaman pertama bagi mereka.

Kajian selanjutnya menunjukkan manfaat yang dirasakan dari Google Classroom. Hasil pengumpulan data survey sebagai berikut:

Tabel 3. Manfaat Google Classroom

\begin{tabular}{clrrc}
\hline No & \multicolumn{1}{c}{ Aspek } & Rata-Rata & \% & Interprestasi \\
\hline 1 & Kegiatan belajar yang luar biasa & 4,12 & 82,40 & Baik \\
\hline 2 & Media yang sangat baik untuk interaksi sosial & 3,88 & 77,60 & Baik \\
\hline 3 & Penyerahan tugas tepat waktu & 3,97 & 79,40 & Baik \\
\hline 4 & Kegiatan belajar yang produktif & 4,04 & 80,80 & Baik \\
\hline 5 & Umpan balik yang berguna dari guru & 3,82 & 76,40 & Baik \\
\hline
\end{tabular}


2878 Penggunaan Google Classroom oleh Siswa dalam Pembelajaran Pendidikan Agama Islam di Masa Pandemic Covid 19 - Aris Fajar Kusumah, Oyoh Bariyah, Khalid Ramdhani

DOI: https://doi.org/10.31004/edukatif.v3i5.1011

\begin{tabular}{|c|c|c|c|c|}
\hline 6 & $\begin{array}{l}\text { Sistem penilaian yang berguna untuk memantau } \\
\text { kemajuan }\end{array}$ & 3,77 & 75,40 & Baik \\
\hline \multirow[t]{2}{*}{7} & Memberikan deskripsi tugas yang jelas & 3,55 & 71,00 & Baik \\
\hline & Rata-Rata & 3,88 & 77,57 & Baik \\
\hline
\end{tabular}

Sajian data di atas menunjukkan persepsi siswa mengenai bagaimana GCR memfasilitasi pembelajaran PAI mereka. Nilai rata-rata untuk semua aspek yang disurvei adalah 3,88 secara verbal, menunjukkan bahwa siswa merasakan manfaat baik/positif. Nilai rata-rata tertinggi adalah pada kegiatan belajar yang luar biasa $(82,40)$. Hal ini tentu temuan yang unik, karena selama ini siswa belajar dengan tatap muka. Dengan adanya pembelajaran dengan GCR, menjadi sebuah aktivitas dan pengalman belajar baru bagi mereka. Sementara itu, rata-rata terendah adalah pemberian deskripsi tugas yang jelas $(3,55)$. Dengan kata lain, siswa merasakan bahwa membutuhkan intruksi tugas yang jelas dari guru sehingga siswa tidak multitafsir dan lebih mudah memahami alur tugas yang harus dikerjakan. Terlepas dari kondisi tersebut, hasil keseluruhan menunjukkan bahwa siswa menilai bahwa bahwa Google Classroom membawa manfaat yang baik bagi pembelajaran.

Survei selanjutnya mengenai komunikasi dan interaksi siswa dalam pembelajaran PAI melalui GCR. Hasilnya dilaporkan sebagai berikut:

Tabel 4. Komunikasi dan Interaksi Siswa

\begin{tabular}{clccc}
\hline No & \multicolumn{1}{c}{ Aspek } & $\begin{array}{c}\text { Rata- } \\
\text { Rata }\end{array}$ & $\boldsymbol{\%}$ & Interprestasi \\
\hline 1 & Saluran komunikasi yang nyaman & 3,94 & 78,80 & Baik \\
\hline 2 & Melibatkan siswa dan diskusi yang produktif & 3,77 & 75,40 & Baik \\
\hline 3 & Berbagi bersama di forum diskusi & 3,43 & 68,60 & Baik \\
\hline 4 & Guru yang antusias dalam mengajar & 4,25 & 85,00 & Baik \\
\hline 5 & Guru yang ramah dan mudah didekati & 3,88 & 77,60 & Baik \\
\hline 6 & Interaksi yang nyaman antar peserta & 3,73 & 74,60 & Baik \\
\hline & Rata-Rata & 3,83 & 76,67 & Baik \\
\hline
\end{tabular}

Hasil analisa secara deskriptif menunjukkan rata-rata 3,83. Ini dapat diartikan bahwa GCR menjadi media yang dianggap baik dan disukai siswa dalam berkomunikasi dan berinteraksi dalam pembelajaran PAI. Rata-rata tertinggi ditunjukkan oleh antusias guru dalam mengajar $(4,25)$, dan rata rata terendah ditunjukkan oleh aspek berbagi bersama di forum diskusi $(3,43)$.

Bagian berikut menampilkan hasil survei mengenai respon siswa untuk pengiriman intruksi di GCR. Data tersebut menunjukkan tingkat opini siswa tentang bagaimana Google Classroom telah digunakan oleh guru PAI untuk menyampaikan instruksi pembelajaran kepada siswa. Instruksi Pengiriman termasuk kejelasn instruksi, tenggat waktu, tpik pembelajaran, aturan partisipasi, dan pemberian umpan balik. Hasilnya sebagai berikut:

Tabel 5. Pengiriman intruksi pembelajaran di GCR

\begin{tabular}{clccc}
\hline No & \multicolumn{1}{c}{ Aspek } & Rata-Rata & \% & Interprestasi \\
\hline 1 & Instruksi yang jelas untuk kegiatan pembelajaran & 3,66 & 73,20 & Baik \\
\hline 2 & $\begin{array}{l}\text { Menampilkan tanggal jatuh tempo atau durasi untuk } \\
\text { beberapa aktivitas }\end{array}$ & 3,71 & 74,20 & Baik \\
\hline 3 & Kejelasan topik bahasan pembelajaran & 3,90 & 78,00 & Baik \\
\hline 4 & Mengarahkan pada tugas pembelajaran & 4,12 & 82,40 & Baik \\
\hline 5 & $\begin{array}{l}\text { Umpan balik untuk pemahaman yang lebih baik } \\
\text { tentang materi pembelajaran }\end{array}$ & 3,96 & 79,20 & Baik \\
\hline Rata-Rata & 3,87 & 77,40 & Baik \\
\hline
\end{tabular}


Data menunjukkan bahwa semua aspek dalam pengiriman instruksional menerima skor yang secara verbal ditafsirkan baik $(3,87)$. Siswa mengklaim guru PAI mampu menggunakan GCR dengan baik untuk penyampaian instruksional dan melakukan kegiatan yang diperlukan. Misalnya, siswa memberi penilaian bahwa guru mempu mengarahkan pada tugas dan tujuan pembelajaran dengan baik $(4,12)$. Demikian pula pada 4 aspek lain dari pemberian intruksi.

Bagian terakhir dari hasil angket mengungkapkan kepuasan siswa dengan penggunaan GCR dalam pembelajaran PAI. Data kepuasan siswa terhadap pembelajaran PAI menggunakan GCR menunjukkan ratarata 3,88 . Ini menggambarkan bahwa siswa mengklaim bahwa mereka merasa puas dengan pembelajaran yang dilakukan.

Tabel 6. Kepuasan Siswa

\begin{tabular}{llrrc}
\hline No & \multicolumn{1}{c}{ Aspek } & Rata-Rata & \% & Interprestasi \\
\hline 1 & Memenuhi tujuan pribadi siswa. & 4,12 & 82,40 & Baik \\
\hline 2 & Platform yang disukai & 4,16 & 83,20 & Baik \\
\hline 3 & $\begin{array}{l}\text { Layanan pembelajaran yang memadai kebutuhan } \\
\text { belajar siswa }\end{array}$ & 3,43 & 68,60 & Baik \\
\hline 4 & Platform pembelajaran yang memotivasi & 3,82 & 76,40 & Baik \\
\hline Rata-Rata & 3,88 & 77,65 & Baik \\
\hline
\end{tabular}

\section{Pengalaman Siswa dalam Pembelajaran PAI Menggunakan Google Classroom}

Pada pengumpulan data, selain siswa menanggapi kuesioner terbuka, beberapa lainnya berbagi pengalaman mereka menggunakan Google Classroom guna mengintensifkan aktivitas mereka yang berkontribusi terhadappembelajaran mereka. Bagian ini menyajikan tiga temuan utama dari data kualitatif. Pertama, peserta mengklaim bahwa Google Classroom telah menghilangkan batas ruang kelas. Mereka dapat mengelola pembelajaran kapan saja dan dimana saja saat guru mengarahkhan mereka menggunakan GCR untuk pembelajaran. Respon siswa menunjukkan bahwa kehidupan mereka menyatu antara kehidupan sosial mereka di media sosial dan aktivitas belajar mereka yang berlangsung di GCR.

"Saya rasa sosmed bukan hanya aktivitas interaksi atau hiburan semata, tetapi seolah sudah menjadi
kegiatan saya setiap saat. Tidak ada jam yang berlalu tanpa mengoperasikan HP seperti memeriksa
pesan yang masuk di IG (Instagram), WA (WhatsApp), dan Facebook, tapi sekarang plus aktiitas GCR
(Google Classroom). Saya memiliki obrolan di medsos, baik itu obrolan IG, obrolan WA, dan obrolan
FB. Kami menghabiskan banyak waktu sibuk mengobrol tentang segala hal, tetapi GCR hanya untuk
urusan sekolah. Dan sekarang saya tidak bisa memisahkan antara sekolah dan kehidupan sosial saya;
saya melakukannya semua sekaligus melalui HP yang saya miliki."
(wawancara dengan SR, Siswa Kelas VIII SMPN 2 Telukjambe)

Dengan pemanfaatan Google kelas sebagai bagian dari proses kelas, tidak ada kejelasan definisi ruang kelas. Terkadang para siswa terus beraktivitas pembelajaran secara mandiri meskipun jadwal pelajaran PAI telah berakhir dan GCR telah ditutup. Para siswa terus berinteraksi sebagai proses kelas resmi yang normal, bukan sebagai jam tambahan ketika mereka mengerjakan pekerjaan rumah. Bagian yang menarik adalah bahwa mereka begitu ketergantungan dengan ponsel mereka sehingga tidak ada waktu tanpa memeriksa aktivitas selular di mana mereka terlibat dalam GCR serta ineraksi media sosial mereka.

Kedua, siswa mengklaim bahwa mengintegrasikan Google Classroom dalam aktiitas pembelajaran meningkatkan kesadaran siswa akan kebuthan belajar mereka. Bahkan, dengan teknologi mereka merasa dipaksa bersikap mandiri untuk fokus pada kemajuan belajar mereka. 
"Google Classroom mengisi dan mengingatkan saya tentang aktivitas belajar yang harus saya lakukan. Sangat sering saya merasa kewalahan ketika saya menerima pemberitahuan dari GCR, bahwa tugas hampir jatuh tempo atau intruksi yang hampir deadline. Meskipun dengan GCR belajar menjadi lebih fleksibel, tapi dalam hal ini saya termotivasi untuk tidak berhenti belajar, kapan saja di mana saja. Waktu yang fleksibel berarti saya dapat menyesuaikan jam belajar dan aktivitas saya lainnya. Bahkan saya biasanya memposting tugas saya tengah malam".

(wawancara dengan AH, Siswa Kelas VIII SMPN 2 Telukjambe)

Kutipan di atas menunjukkan bahwa siswa menjadi lebih terikat dengan kelas mereka. Sifat fleksibel bahkan menuntut mereka untuk meningkatkan komitmen untuk selalu kembali ke kegiatan terkait sekolah di tengah kesibukan mereka dalam rutinitas media sosial.

"Saya rasa ponsel adalah bagian dari keseharian hidup saya. Saya menghabiskan berjam-jam
dengan gadget saya. Selama seingat saya, jam tidur saya mengalami perubahan sejak saya aktif
di medsos. Dan kini ditambah lagi dengan GCR, bahkan malam hari saya tidak bisa berhenti
mengklik, mendengarkan, menonton, membaca sampai saya lupa waktu, lupa melakukan
sesuatu. Saya tidak tahu apa yang saya lakukan, tetapi saya tetap tidak boleh menyerah. Saya
tidak tahu apakah saya sedang belajar atau tidak, tetapi yang pasti saya selalu menggunakan
ponsel saya baik medsos maupun GCR".
(wawancara dengan RN, Siswa Kelas VIII SMPN 2 Telukjambe)

Berbeda dengan dua temuan pertama, poin ketiga menunjukkan bahwa siswa kesal dengan menciptakan kehidupan baru dan kebiasaan baru. Mereka kewalahan dengan informasi dan hiburan menarik yang dirantai melalui gadget mereka dan mendapati diri mereka membuang-buang waktu untuk kegiatan yang tidak produktif. Mereka sebenarnya sadar bahwa mereka menunda hal-hal yang seharusnya mereka lakukan; dalam banyak kasus, mereka tidak tahu apa dan mengapa sebenarnya mereka melakukannya. Bahkan menyiratkan bahwa siswa memilikih kecanduan gadget sehingga aktivitas studi mereka mengalami ganggun atau masalah.

Pemanfaatan berbagai platform pembelajaran online kian berkembang seiring dengan dipromosikan dan semakin populernya pembelajaran online. Berbagai penelitian dilaporkan tentang bagaimana pendidik atau guru menggunakan platform yang berbeda seperti Moodle (Eskandari \& Soleimani, 2016), Edmodo (Halil, 2020), Google Kelas (Abid Azhar \& Iqbal, 2018), WebCT (Mathew, 2014), dan alat online atau berbasis cloud lainnya (Butnaru et al., 2021). Platform pembelajaran diatas menjadi popular karena manfaatnya dalam mempromosikan keterlibatan intensif dalam kegiatan belajar yang dibuktikan dengan interaksi yang lebih besar antara siswa dengan guru. Penggunaan platform pembelajaran online dapat mengubah penyampaian instruksional dengan cara yang lebih fleksibel dan simple.

Pembahasan diatas sejalan dengan hasil penelitian saat ini. Kemudahan akses dan manfaat yang dirasakan dari GCR menunjukkan bahwa rutinitas sehari-hari siswa berinteraksi di media sosial mereka diinegrasikan dengan kegiatan akademik yang difasilitasi oleh GCR. Dengan ini, para siswa meningkatkan komitmen mereka untuk belajar dan meningkatkan pembelajaran mereka. Misalnya, saat menggunakan WhatsApp, Instagram, Facebook, dan akun media sosial lainnya untuk berinteraksi dengan jaringan mereka, hasilnya menunjukkan bahwa siswa secara bersamaan berpartisipasi dalam GCR. Siswa mengklaim bahwa Google Classroom telah membawa Pembelajaran PAI ke hadapan ingatan, berarti terjadi kedekatan antara hubungan sosial dan akademik. Temuan penelitian penulis memperkuat hasil studi Silalahi \& Hutauruk (2020), yang mengklaim bahwa pembelajaran online memberikan waktu dan lingkungan yang fleksibel meningkatkan komitmen siswa untuk belajar mereka. 
Selanjutnya, Freeman (2019) berpendapat bahwa komitmen belajar sangat penting untuk keberhasilan pembelajaran dalam realitas serba cepat abad kedua puluh satu. Komitmen siswa dapat menyelamatkan mereka dari aktivitas yang tidak relevan dan eksplorasi tidak produktif yang diintensifkan oleh media sosial. Lebih lanjut Lemoine et al., (2020) dalam studinya mengklaim bahwa pengenalan teknologi tampaknya tidak terwujud dalam pengajaran tugas secara online, karena faktanya bisa saja seorang siswa yang melek teknologi tidak mungkin selalu melakukannya dengan baik di berbagai gangguan atau lingkungan belajar yang berbeda. Tresnaningsih et al (2019) mengatakan bahwa siswa perlu berjuang untuk membiasakan diri dengan kegiatan terkait sekolah dan tugas akademik di antara berbagai gangguan media online. Ada terlalu banyak kegiatan yang bersaing di benak siswa di tengah lingkungan yang kaya teknologi. Guru harus memastikan bahwa komitmen positif siswa memenangkan mereka mencapai tujuan pembelajaran.

Selain itu, penelitian saat ini menunjukkan bahwa GCR memberikan kesempatan yang lebih luas bagi siswa untuk berkumpul dengan teman sebaya serta melanjutkan pekerjaan sekolah mereka. Data dari kuesioner menunjukkan bahwa GCR telah membantu mereka menerima tugas $(4,33)$ dan mengumpulkan tugas tepat waktu $(4,41)$. Siswa juga mengklaim bahwa fleksibilitas pembelajaran berarti tidak hanya memungkinkan mereka untuk menyesuaikan jam belajar mereka, tetapi juga untuk meningkatkan komitmen mereka untuk bekerja sampai tengah malam. Kemampuan siswa untuk mempertahankan keterlibatan mereka untuk bekerja begitu keras menunjukkan disposisi positif siswa tanpa dirusak oleh banyaknya gangguan lain yang mendesak dan menonjol. Hasil penelitian ini sejalan dengan studi Satar \& Akcan (2018) yang mengungkap bahwa GCR menghargai hasil yang konstruktif pada upaya belajar siswa serta partisipasi aktif dalam pembelajaran sehingga dapat menghasilkan sikap positif untuk jenis pembelajaran berbasis teknologi terkini. Demikian pula dengan studi Amadin et al (2018) yang mengungkap bahwa Google Classroom memungkinkan siswa untuk mencapai tugas sekolah yang lebih baik dan meningkatkan produktivitas belajar.

Sejumlah penelitian justru menunjukkan temuan serupa dengan temuan dan hasil penelitian ini. Penelitian menemukan bahwa siswa memperoleh pengalaman dan perasaan antara termotivasi dan optimis dengan akses ke dunia akses informasi yang kaya, tetapi pada saat yang sama dibebani dengan gangguan kebiasaan media social mereka. Penelitian Asrivi (2020) menemukan bahwa meskipun sebagian siswa merasa terganggu oleh akses informasi simultan, berhasil menyelesaikan pekerjaan mereka. Demikian pula dengan Conard \& Marsh (2014) berpendapat bahwa siswa mereka menggunakan beberapa menggunakan strategi multitasking yang menguntungkan tugas belajar mereka.

Temuan lain penelitian ini mengungkap bahwa dengan memanfaatkan Google Classroom, dirasakan keefektifannya dalam pembelajaran PAI. Efektivitas pembelajaran dengan Google Classroom terlihat dari adanya peningkatan kualitas belajar siswa dari waktu ke waktu. Ini sejalan dengan penelitian Rahmanto \& Bunyamin (2020) yang menjelaskan bahwa efektifitas Google Classroom dapat dilihat dari hasil belajar siswa yang semakin meningkat setiap harinya melalui tugas dan kuis.

Google classroom merupakan teknologi yang dirancang guna memudahkan pembelajaran berbasis online dan jarak jauh (Salamah, 2020). Kebermanfaatannya dalam akses, kemudahan mengoperasikan hingga membantu tujuan belajar tentu dirasakan oleh banyak pihak. Melalui pemanfaatan aplikasi Google classroom, siswa dan guru mampu meningkatkan kualitas pembelajaran tanpa dibatasi ruang dan waktu dengan beragam sumber belajar yang variatif dan inovatif berbasis internet. Namun sehebat apapun teknologi tentu memiliki keterbatasan, dimana keberadaannya secara psikologis dan emosional tidak dapat menggantikan kehadiran guru di kelas. Teknologi pembelajaran secanggih apapun, hanya bernilai materi tak bergerak jika berada di tangan guru yang tidak kompeten. Sebaliknya, aplikasi apabila berada di tangan guru yang hebat maka akan mampu melakukan transformasi pembelajaran.

Kendati sebagian besar penelitian menunjukkan manfaat positif dan efektivitas Google Classroom, namun terlepas dari manfaat tersebut untuk memiliki akses ke teknologi informasi dan komunikasi, beberapa siswa masih gagal untuk mendapatkan manfaat dari teknologi. Temuan ini sejalan dengan hasil penelitian 
Abid Azhar \& Iqbal (2018) menjelaskan bahwa tentunya sangat disayangkan manakala masih ditemukan siswa terganggu dan bahkan diperburuk oleh teknologi. Teknologi benar-benar diciptakan untuk membantu umat manusia tetapi bagi mereka yang gagal mengatur diri sendiri akan dirugikan. Studi mengenai pemanfaatan aplikasi dalam pembelajaran online di masa pandemic, sebagaimana kajian Putra et al (2020) mencontohkan bagaimana siswa terjebak oleh teknologi karena ketidakmampuan mereka untuk memprioritaskan studi dan kehidupan mereka. Mereka gagal memahami penggunaan teknologi untuk pembelajaran. Mereka memang membutuhkan bantuan dan upaya keras untuk kembali ke Google Classroom mereka dan berhenti menunda-nunda pencapaian tujuan belajar (Putra et al., 2020). Dengan demikian temuan lain dan simpulan lain penelitian ini justru mengungkap bahwa kendati Google Classroom menjadikan pembelajaran PAI terlaksana secara efektif, akan tetapi sebagian siswa justru mengalami masalah serius dengan kecanduan game online dan media sosial. Ini membuat mereka kesulitan mengontrol diri untuk mengarahkan pada pembelajaran.

\section{KESIMPULAN}

Google Classroom (GCR) menjadi platform yang efektif dalam mengoptimalkan pembelajaran online PAI di masa pandemic Covid 19. Studi melaporkan aspek-aspek pemanfaatan GCR seperti akses, kegunaan, komunikasi, penyampaian instruksional, dan kepuasan siswa secara keseluruhan serta keterlibatan mereka menggunakan GCR untuk pembelajaran siswa berjalan dengan baik. Siswa tidak kesulitan mengakses fasilitas yang disediakan oleh Google Classroom guna mendukung pembelajaran. Oleh karena itu, mereka memperoleh manfaat untuk membantu mereka menyerahkan tugas tepat waktu, mendapatkan umpan balik dari guru, dan deskripsi pembelajaran dan komunikasi dengan guru dan siswa lain. Secara keseluruhan, siswa puas menggunakan Google Classroom dalam pembelajaran. Kendati penelitian membahas temuan positif, akan tetapi temuan lain membahas bahwa masih adanya siswa kecanduan media sosial dan ketergantungan terhadap gadget sehingga mereka kesulitan mengontrol perilaku untuk melakukan pembelajaran yang lebih baik.

\section{DAFTAR PUSTAKA}

Abid Azhar, K., \& Iqbal, N. (2018). Effectiveness Of Google Classroom: Teachers' Perceptions. Prizren Social Science Journal, 2(2), 52-66.

Ali, M. K., \& Maksum, H. (2020). Utilization Of E-Learning-Based ICT Learning Using The Google Classroom Application During The COVID-19 Pandemic. Journal Of Education Research And Evaluation, 4(4), 373-379. Https://Doi.Org/10.23887/Jere.V4i4.29181

Amadin, F. I., Obienu, A. C., \& Osaseri, R. O. (2018). Main Barriers And Possible Enablers Of Google Apps For Education Adoption Among University Staff Members. Nigerian Journal Of Technology, 37(2), 432. Https://Doi.Org/10.4314/Njt.V37i2.18

Asmawati, E., \& Bintang Kejora, M. T. (2020). The Effect Of Using Simple Aircraft Concrete Media On The Mastery Of Concepts In Inquiry Science Learning In Elementary School Students. Mudarrisa: Jurnal Kajian Pendidikan Islam, 12(2), 150-168. Https://Doi.Org/10.18326/Mdr.V12i2.150-168

Asrivi, Q. E. S. (2020). Pembelajaran Daring Melalui Google Classroom Mata Kuliah Pembelajaran Tematik Terpadu Mahasiswa Pgmi Iai Bakti Negara Tegal Dalam Menghadapi Pandemi Covid-19. Jurnal Holistika, 4(2), 77-84.

Butnaru, G. I., Niță, V., Anichiti, A., \& Brînză, G. (2021). The Effectiveness Of Online Education During Covid 19 Pandemic - A Comparative Analysis Between The Perceptions Of Academic Students And High School Students From Romania. Sustainability (Switzerland), 13(9). 
2883 Penggunaan Google Classroom oleh Siswa dalam Pembelajaran Pendidikan Agama Islam di Masa Pandemic Covid 19 - Aris Fajar Kusumah, Oyoh Bariyah, Khalid Ramdhani DOI: https://doi.org/10.31004/edukatif.v3i5.1011

Https://Doi.Org/10.3390/Su13095311

Conard, M. A., \& Marsh, R. F. (2014). Interest Level Improves Learning But Does Not Moderate The Effects Of Interruptions: An Experiment Using Simultaneous Multitasking. Learning And Individual Differences, 30, 112-117. Https://Doi.Org/10.1016/J.Lindif.2013.11.004

Creswell, J. W. (2014). Research Design Qualitative, Quantitative, And Mixed Method Approaches. SAGE Publication. Inc.

Dewi, W. A. F. (2020). Dampak COVID-19 Terhadap Implementasi Pembelajaran Daring Di Sekolah Dasar. Edukatif: Jurnal Ilmu Pendidikan, 2(1), 55-61. Https://Doi.Org/10.31004/Edukatif.V2i1.89

Efriana, L. (2021). Problems Of Online Learning During Covid-19 Pandemic In EFL Classroom And The Solution. Journal Of English Language Teaching And Literature, 2(1), 38-47.

El Fauziah, U. N., Suryani, L., \& Syahrizal, T. (2019). Penerapan Google Classroom Dalam Pembelajaran Bahasa Inggris Kepada Guru-Guru Bahasa Inggris Smp Di Subang. Abdimas Siliwangi, 2(2), 183. Https://Doi.Org/10.22460/As.V2i2p183-191.3281

Eskandari, M., \& Soleimani, H. (2016). The Effect Of Collaborative Discovery Learning Using MOODLE On The Learning Of Conditional Sentences By Iranian EFL Learners. Theory And Practice In Language Studies, 6(1), 153. Https://Doi.Org/10.17507/Tpls.0601.20

Freeman, H. (2019). The Concept Of Teaching. Journal Of Philosophy Of Education, 7(2), 5-8. Https://Doi.Org/10.1111/J.1467-9752.1973.Tb00470.X

Gan, B., Menkhoff, T., Smith, R. R., Enhancing, R. R., Gan, B., Menkhoff, T., \& Smith, R. (2015). Institutional Knowledge At Singapore Management University Enhancing Students ' Learning Process Through Interactive Digital Media: New Opportunities For Collaborative Learning Computers In Human Behavior Enhancing Students' Learning Process Through Int. Computers In Human Behavior, 652-663.

Halil, N. I. (2020). The Effectiveness Of Using Edmodo As An Online Learning Platform In Covid-19. Jurnal Penelitian Dan Pengkajian Ilmu Pendidikan: E-Saintika, 4(3), 284. Https://Doi.Org/10.36312/ESaintika.V4i3.316

Handarini, O. I. (2020). Pembelajaran Daring Sebagai Upaya Study From Home (SFH) Selama Pandemi Covid 19 Oktafia. Jurnal Pendidikan Administrasi Perkantoran (JPAP), 8(3), 496-503. Https://Doi.Org/10.1093/Fampra/Cmy005

Hapsari, S. A., \& Pamungkas, H. (2019). Pemanfaatan Google Classroom Sebagai Media Pembelajaran Online Di Universitas Dian Nuswantoro. Wacana: Jurnal Ilmiah Ilmu Komunikasi, 18(2). Https://Doi.Org/10.32509/Wacana.V18i2.924

Indrawati, B. (2020). Tantangan Dan Peluang Pendidikan Tinggi Dalam Masa Dan Pasca Pandemi Covid-19. Jurnal Kajian Ilmiah, 1(1), 39-48. Https://Doi.Org/10.31599/Jki.V1i1.261

Lemoine, P. A., Waller, R. E., Garretson, C. J., \& Richardson, M. D. (2020). Examining Technology For Teaching And Learning. Journal Of Education And Development, 4(2), 80 Https://Doi.Org/10.20849/Jed.V4i2.781

Mahyoob, M. (2020). Challenges Of E-Learning During The COVID-19 Pandemic Experienced By EFL Learners. Arab World English Journal, 11(4), 351-362. Https://Doi.Org/10.24093/Awej/Vol1 1no4.23

Mathew, D. (2014). E-Learning, Time And Unconscious Thinking. E-Learning And Digital Media, 11(2), 135-140. Https://Doi.Org/10.2304/Elea.2014.11.2.135

Moleong, L. J. (2018). Metodologi Penelitian Kualitatif [Qualitative Research Methodology]. PT Remaja Rosdakarya.

Mu'minah, I. H., \& Gaffar, A. A. (2020). Optimalisasi Penggunaan Google Classroom Sebagai Alternatif Digitalisasi Dalam Pembelajaran Jarak Jauh (Pjj). Bio Educatio : (The Journal Of Science And Biology 
2884 Penggunaan Google Classroom oleh Siswa dalam Pembelajaran Pendidikan Agama Islam di Masa Pandemic Covid 19 - Aris Fajar Kusumah, Oyoh Bariyah, Khalid Ramdhani DOI: https://doi.org/10.31004/edukatif.v3i5.1011

Education), 5(2), 23-36. Https://Doi.Org/10.31949/Be.V5i2.2610

Mustakim, M. (2020). Efektivitas Pembelajaran Daring Menggunakan Media Online Selama Pandemi Covid19 Pada Mata Pelajaran Matematika. Al Asma: Journal Of Islamic Education, 2(1), 1. Https://Doi.Org/10.24252/Asma.V2i1.13646

Nurabadi, A., Irianto, J., Bafadal, I., Juharyanto, Gunawan, I., \& Adha, M. A. (2021). The Effect Of Instructional, Transformational And Spiritual Leadership On Elementary School Teachers' Performance And Students' Achievements. Cakrawala Pendidikan, 40(1), 17-31. Https://Doi.Org/10.21831/Cp.V40i1.35641

Pokhrel, S., \& Chhetri, R. (2021). A Literature Review On Impact Of COVID-19 Pandemic On Teaching And Learning. Higher Education For The Future, 8(1), 133-141. Https://Doi.Org/10.1177/2347631120983481

Putra, P., Liriwati, F. Y., Tahrim, T., Syafrudin, S., \& Aslan, A. (2020). The Students Learning From Home Experiences During Covid-19 School Closures Policy In Indonesia. Jurnal Iqra': Kajian Ilmu Pendidikan, 5(2), 30-42. Https://Doi.Org/10.25217/Ji.V5i2.1019

Rahardjo, A., \& Pertiwi, S. (2020). Learning Motivation And Students' Achievement In Learning English: A Case Study At Secondary School Students In The Covid-19 Pandemic Situation Agus Rahardjo. JELITA: Journal Of English Language Teaching And Literature, 1(2), 2721-1916.

Rahayu, R. P., \& Wirza, Y. (2020). Teachers' Perception Of Online Learning During Pandemic Covid-19. Jurnal Penelitian Pendidikan, 20(3), 392-406. Https://Doi.Org/10.17509/Jpp.V20i3.29226

Rahmanto, M. A., \& Bunyamin. (2020). Efektivitas Media Pembelajaran Daring Melalui Google Classroom. Jurnal Pendidikan Islam, 11(November), 119-135.

Sabran, \& Sabara, E. (2019). Keefektifan Google Classroom Sebagai Media Pembelajaran. Prosiding Seminar Nasional Lembaga Penelitian Universitas Negeri Makasar, 122-125. Https://Webcache.Googleusercontent.Com/Search?Q=Cache:SS_Jkm_R2taj:Https://Ojs.Unm.Ac.Id/Sem naslemlit/Article/Download/8256/4767+\&Cd=2\&Hl=Id\&Ct=Clnk\&Gl=Id

Salam, U. (2020). The Students' Use Of Google Classroom In Learning English. JPI (Jurnal Pendidikan Indonesia), 9(4), 628-638. Https://Doi.Org/10.23887/Jpi-Undiksha.V9i4.27163

Salamah, W. (2020). Deskripsi Penggunaan Aplikasi Google Classroom Dalam Proses Pembelajaran. Jurnal Penelitian Dan Pengembangan Pendidikan, 4(3), 533-538.

Satar, H. M., \& Akcan, S. (2018). Pre-Service EFL Teachers' Online Participation, Interaction, And Social Presence. Language Learning And Technology, 22(1), 157-184.

Saunders, M., Lewis, P., \& Thornhill, A. (2016). Research Methods For Business Students (7th Ed.). Pearson Education Limited.

Silalahi, T. F., \& Hutauruk, A. F. (2020). The Application Of Cooperative Learning Model During Online Learning In The Pandemic Period. Budapest International Research And Critics Institute (BIRCIJournal): Humanities And Social Sciences, 3(3), 1683-1691. Https://Doi.Org/10.33258/Birci.V3i3.1100

Sugiyono. (2016). Metode Penelitian Kombinasi (Mix Methode). Alfabeta.

Suharsaputra, U. (2012). Metode Penelitian Kuantitaif Kualitatif Dan Tindakan. Refika Adhitama.

Taufik, M. (2020). Strategic Role Of Islamic Religious Education In Strengthening Character Education In The Era Of Industrial Revolution 4.0. Jurnal Ilmiah Islam Futura, 20(1), 86. Https://Doi.Org/10.22373/Jiif.V20i1.5797

Tresnaningsih, F., Santi, D. P. D., \& Suminarsih, E. (2019). Kemandirian Belajar Siswa Kelas Iii Sdn Karang Jalak I Dalam Pembelajaran Tematik. Pedagogi: Jurnal Penelitian Pendidikan, 6(2), 51-59. Https://Doi.Org/10.25134/Pedagogi.V6i2.2407

Tsai, C.-C., Cheng, Y.-M., Tsai, Y.-S., \& Lou, S.-J. (2021). Impacts Of AIOT Implementation Course On The 
2885 Penggunaan Google Classroom oleh Siswa dalam Pembelajaran Pendidikan Agama Islam di Masa Pandemic Covid 19 - Aris Fajar Kusumah, Oyoh Bariyah, Khalid Ramdhani

DOI: https://doi.org/10.31004/edukatif.v3i5.1011

Learning Outcomes Of Senior High School Students. Education Sciences, 11(2), 82. Https://Doi.Org/10.3390/Educsci11020082

Wahyuningsih, K. S. (2021). Problematika Pembelajaran Daring Di Masa Pandemi Covid-19 Di Sma Dharma Praja Denpasar. Jurnal Pangkaja, 24(1), 107-118.

Wicaksono, V. D., \& Rachmadyanti, P. (2016). Pembelajaran Blended Learning Melalui Google Classroom Di Sekolah Dasar. Seminar Nasional Pendidikan PGSD UMS \& HDPGSDI Wilayah Timur, 513-521. Http://Hdl.Handle.Net/11617/9144

Widodo, A., \& Nursaptini. (2020). Problematika Pembelajaran Daring Dalam Perspektif Mahasiswa. ELSE (Elementary School Education Journal), 04(02), 100-115. 